\title{
Reported Experiences Enhance Favourable Attitudes Toward Toads
}

\author{
Iztok TOMAŽIČ \\ University of Ljubljana, Ljubljana, SLOVENIA
}

Received 13 January 2011; accepted 27 July 2011

\begin{abstract}
There are many factors that influence the formation of attitudes, one of the most crucial ones being education. Positive attitudes toward animals can be effectively accomplished principally by enabling students to directly experience organisms and their environments. The following study presents the development of a Toad Attitude Questionnaire (TAQ). Results were gathered from a sample of 195 primary school students (grades 6-9, ages 1114). Results show, that students who reported direct experience with animals were more willing to study animals and generally exhibited a more positive attitude toward them. Implications of the study are discussed.
\end{abstract}

Keywords: Attitude, Animals, Toads, Reported Direct Experience

\section{INTRODUCTION}

Amphibians have been in the past two decades of great concern for many biologists, as their numbers have decreased radically. Some even link amphibian declines with next, sixth mass extinction of species. According to the IUCN Red List of Threatened Species (IUCN, Conservation International, and NatureServe, 2008), over 6000 species of amphibians were found and described and over one third has undergone severe decline or is facing worldwide extinction. Namely, habitat destruction and exploitation, climate change, increasing levels of ultraviolet radiation, environmental contamination, disease, and the introduction of nonnative species are all possible causes for which amphibian numbers are in decline (Beebee \& Griffith, 2005; Blaustein \& Kiesecker, 2002).

For conservation biology, education plays the important role through which biologists can present novel environmental problems to the general public, first to inform them about those problems and second to motivate people to take actions for preserving healthy environments. In the year 2004, the Society for

Correspondence to: Iztok Tomažic, Ph.D of Biology Didactics, University of Ljubljana, Biotechnical Faculty, Department of Biology, Večna pot 111, SI-1001 Ljubljana, SLOVENIA

E-mail: iztok.tomazic@bf.uni-lj.si
Conservation Biology published Conservation literacy guidelines (Trombulak et al., 2004). For protection and restoration of biological diversity, ecological integrity, and ecological health, the authors set conservation biology education as one of the most important goals. They propose that educators should seek to develop in people a deeper understanding of the importance and tools of conservation biology; propose that education is the most effective when people develop knowledge, skills, and attitudes through direct experience and that conservation biologists have a unique set of knowledge, skills, and concerns to share with others.

To support this view, one conservation action concerning amphibians must be mentioned, where educated farmer stopped using agro-chemicals on his fields and when the population of local frogs was increasing, the farmer also became a follower of an organic lifestyle and was proud of the local frog species on his land (Lin et al., 2008). Also, in the year 2008 there was global awareness campaign organised by the Association of Zoos and Aquariums, who declared this year as "The Year of the Frog". Their special focus was on the public promotion of this highly endangered species (amphibians) to raise awareness that the crisis must be addressed (Association of Zoos and Aquariums, n.d.).

Several authors argue that Slovenian general public is ambivalent when amphibians are of concern, and not tolerant to toads living near their homes (Gregori, 1996; Tomažič, 2008). According to the author's experience 


\section{State of the literature}

- There is evidence that direct experience with animals contributes to the formation of positive attitudes toward animals.

- Questionnaires that use Likert type scales are frequently used to test participants' attitude toward animals, so the results should be comparable to other studies.

\section{Contribution of this paper to the literature}

- In this paper the author assessed attitude toward amphibians.

- Direct experience might influence attitudes toward toads, lowers negative feelings toward animals and heightens interest in studying these animals.

- Males display less interest for animals and are not so opposed to inappropriate behaviour toward toads than females.

many believe that "slimy" toads can give warts to people. Some also believe, if toads excrete on them, they can be poisoned.

Children are learning about amphibians (animals) in schools. Although schools are considered as one of the most powerful institutions which can, and should play an important role in addressing environmental issues (Hungerford \& Volk, 1990) that is not always the case. For example, students do not report schools as one of the main sources of information about animals (Tunnicliffe \& Reiss, 1999). The following question can be raised: "Are biology teachers prepared to teach such topics to the children?" They have, according to Kellert (1996), a pivotal role in educating environmentally responsible citizens. If teachers would present animals only in a form of building students factual knowledge that would not necessarily suffice for a development of positive attitudes and skills, as it was confirmed in a case of snakes (Morgan \& Gramann, 1989; Morgan, 1992; Prokop et al., 2009b).

Research of attitude toward different animals and animal groups has been gaining much attention lately both in terms of assessing students' views of various animals and the application of findings in the field of conservation biology. Kellert (1985) found that when starting with children aged six to nine, the best way is to focus on the affective realm, mainly emphasising emotional concern and sympathy for animals; followed by the promotion of cognitive or factual understanding in 10 to 13 year-olds; and finally, after the age of 13, building on ethical concerns for animals and an understanding of ecology. Animals that draw much attention in attitude research are either charismatic animals such as dolphins (Barney et al., 2005) and primates (Lukas \& Ross, 2005) or the animals that people are usually afraid of, like sharks (Thompson \& Mintzes, 2002), snakes, spiders, bats (Prokop \& Tunnicliffe, 2008, 2010; Prokop et al., 2009a,b) and invertebrates (Kellert, 1993).

Amphibians are class of animals toward which the attitude of students has been with few exceptions, scarcely researched (Randler et al., 2005; Tomažič, 2008). Children do not fear them as much as they are disgusted by them (Tomažič, 2011). Same as fear, disgust is a basic emotion (Ekman, 1999). It is supposed to be an evolved response to object in the environment that represent treats of infectious disease (Curtis \& Biran 2001; Curtis et al., 2004; Oaten et al., 2009; Prokop et al. 2010a; Prokop et al., 2010c). Several studies that focused on fear of animals included only one amphibian species (frog). After statistical analysis, those studies dismissed these animals because they failed to categorise within a certain group of organisms factor (Arrindell, 2000; Davey et al. 1998). Therefore results of those studies cannot be compared to the study of Tomažič (2008, 2011), who found that, when amphibian species are used in instruction, children's affection of animals improves considerably. It seems that direct experience of animals gained before instruction as well as animals used within instruction defines more stable and confident attitude than only instruction where no live animals are used. That is in line with research from psychology, where basic assumption about attitudes is that they 'guide, influence, direct, shape or predict behaviour' (Kraus, 1995). If attitudes are based on direct experience they are 'more persistent, stronger, held with greater certainty, more stable over time and more resistant to counterinfluence' (Fazio \& Zanna, 1981).

\section{Current study}

No questionnaire to the knowledge of the author has been yet developed, which assessed children's attitude toward amphibian species. Tomažič (2008) in his research asked students only on one attitude dimension, namely if they liked, disliked or felt neutral about three amphibian species, leaving other attitudinal dimensions unexplored. In the present study, the author:

(1) developed a questionnaire with which it would be possible to measure changes on different attitude dimensions as a result of different types of instruction.

(2) assessed potential differences in ratings on individual attitude dimension according to primary school students class grade, students' gender and reported direct experiences of toads.

(3) assessed correlations between different attitudinal dimensions according to primary school students class grade, gender and reported direct experiences with toads. 


\section{METHODS}

This work is the follow-up study that was conducted in a year 2004/2005, where the effect of different types of instruction on seventh grade students' knowledge about and attitude toward amphibians was investigated (Tomažič, 2008). The limitation of mentioned study was that the author investigated only students' ratings of liking - disliking for several amphibian species.

The present study took place in September and October 2009. The study was conducted as a part of the project entitled "Development of Natural Science Competences" performed at the Faculty of Natural Sciences of University of Maribor.

\section{Participants}

A total of 195 students from three primary schools attending grades six $(\mathrm{N}=36$; age: $\mathrm{M}=11.0, \mathrm{SD}=0.0)$, seven $(\mathrm{N}=71$; age: $\mathrm{M}=11.9, \mathrm{SD}=0.3)$, eight $(\mathrm{N}=42$; age: $\mathrm{M}=13.1, \mathrm{SD}=0.3)$ and nine $(\mathrm{N}=46$; age: $\mathrm{M}=14.0$,
$\mathrm{SD}=0.2$ ), were chosen for testing the toad attitude questionnaire. There were no statistically significant differences in frequency distribution of students according to gender and reported direct experiences with toads $\left(\chi^{2}=0.88, \mathrm{df}=1, \mathrm{p}=0.349\right)$. However, there were statistically significant differences between frequency distribution of students according to grade and reported direct experiences with toads $\left(\chi^{2}=25.00\right.$, $\mathrm{df}=3, \mathrm{p}<0.001)$. More students of lower grades reported having direct experiences with toads than higher grade students. One of the reasons could be the implementation of new curricula that to greater extent as the former encourages teachers to introduce students to live animals and take students to local ecosystems (i.e. in sixth grade students learn about anthropogenic ecosystems and in seventh grade students are learning about natural ecosystems). Namely, ninth grade students went from fifth grade (age=11) of the old eight year school system to the seventh grade $($ age $=12)$ of the renewed nine year school system. Amphibians are introduced within science curricula in sixth and seventh

Table 1. Distribution of statements on different attitudinal dimensions.

\begin{tabular}{llc}
\hline ITEMS & \multicolumn{2}{c}{ FACTOR } \\
\cline { 2 - 3 }
\end{tabular}

\section{Scientistic}

I would like to learn about different species of toads.

0.804

I would like to learn about environments where toads live.

0.791

0.761

0.725

0.649

0.642

0.573

0.495

0.443

I could observe toads for a long time.

\section{Negativistic}

When I am walking through the woods, I do not have a special wish to meet a toad. (R)

0.721

0.711

0.699

0.649

0.602

0.521

0.511

0.493

Toads are ugly. (R)

\section{Moralistic (Ecologistic)}

We don't need to protect rain forests, because toads living there will move elsewhere. (R) - Ecologistic

It would be for the best if all toads were killed. (R) - Moralistic

Toads need to have rights too.- Moralistic

I wouldn't like to hunt toads. - Moralistic

Hunting toads for fun is cruel. - Moralistic

Keeping toads in captivity is cruel. - Moralistic

0.545

Toads are very important in nature. - Ecologistic

0.543

Toads are of value as they eat mosquitoes and other bugs. - Ecologistic

0.526

Crombach $\alpha$ (for all 25 items 0.88 )

0.510


grade and within systematics and evolution in eighth grade. Although students learn about amphibians even in lower grades, they scarcely meet live animals in instruction.

\section{Instrument}

There are 19 species of amphibians presently living in Slovenia, among which two species of toads can be found; common toad (Bufo bufo) and green toad (Bufo viridis). The former is generally well known species and is widespread in Slovenia. All 19 amphibian species are listed in Slovenian red list of endangered species (Ur. 1. RS, n. 82/2002).

A Toad Attitude Questionnaire (TAQ) was constructed on a basis of other research which employed Kellert's typology (Barney et al., 2005; Kellert, 1985; Thompson \& Mintzes, 2002). A single animal species was selected because it was presumed that measuring a generalised attitude toward amphibians would not yield concrete or valid results (for a discussion see Prokop \& Tunnicliffe, 2010). For example, if rating amphibians, students could think about turtles - reptiles or only frogs - the prototypical species for amphibians (Yen et al., 2004).

Children completed the TAQ that consisted of initial 35 items. The questionnaire was submitted to Factor analysis (with Varimax rotation). After the initial analysis, we decided to retain 25 items that produced three meaningful factors (Table 1). KMO of 0.876 and Bartlett's test of sphericity $(1618.5, \mathrm{df}=300, \mathrm{p}<0.001)$ supported the use of factor analysis. Total variance explained by three-factor solution was $47.8 \%$. The first extracted factor accounted for $28.8 \%$ of total variance.

Cronbach's alpha for the total scale of final 25 items was 0.88. Cronbach's alpha for the first factor was 0.88 (nine items), second factor 0.80 (eight items) and third factor 0.74 (eight items). Factor 1 was named "Scientistic", where students rated their interest in the physical attributes and biological functioning of animals and their interest in direct experience of animals. Factor 2 was named "Negativistic", where children expressed an orientation toward active avoidance of animals as a result of disliking, fear or disgust. The third factor contained statements describing more than one attitudinal dimension (Tab. 1). According to the prevalence of statements of moral and ecologistic attitudes, this factor was named "Moralistic/Ecologistic" (i.e. concern about the right or wrong treatment of animals and concern for the environment as a system and for interrelationships of wildlife species and the natural habitats).

\section{RESULTS}

Effect of grade, gender, and reported direct experience with toads

Statistically significant differences between different grades were found only for "Scientistic" attitudinal dimension (Kruskall-Wallis test: $\chi^{2}=10.830$; df $=3$; $\mathrm{p}$ $=0.013)$. Although the results in different grades are

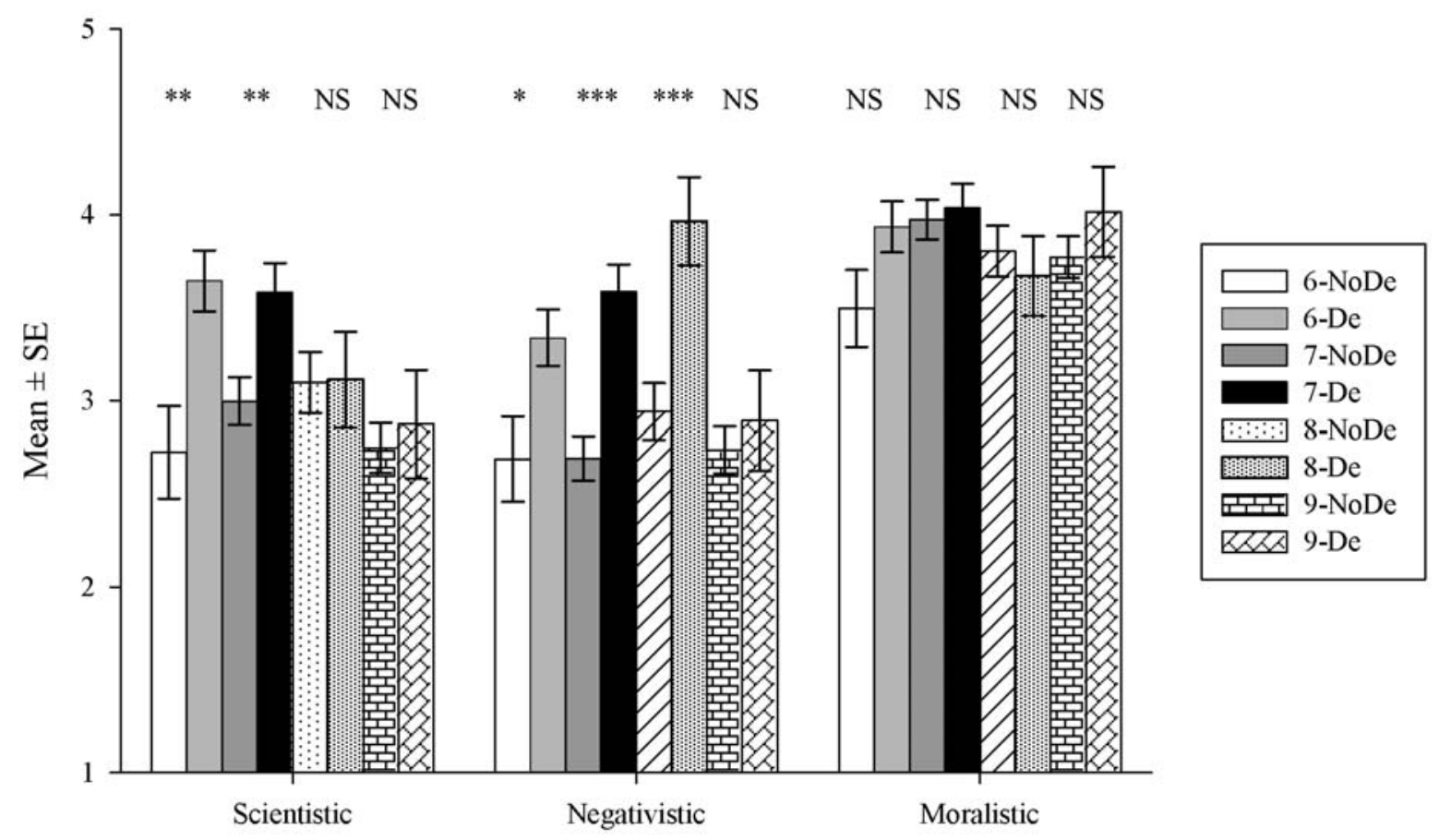

Figure 1. Differences in attitudes toward toads according to grade and reported direct experiences with animals. Lower score on negativistic scale means more negative attitude toward toads.

*** $p<0.001 ; * * p<0.01 ; * p<0.05$; NS = not significant. Legend: number $=$ grade, NoDe $=$ no reported direct experience, $\mathrm{De}=$ reported direct experience. 
comparable, it is obvious that older students are less motivated to study toads than younger students. This interest is diminishing from sixth (age 11) to ninth grade (age 14); from average 3.4, SD $=1.00$ to average $2.8, S D$ $=0.76)$. There were no statistically significant differences between students' ratings on "Negativistic" attitudinal dimension (Kruskall-Wallis test: $\chi^{2}=5.508$; $\mathrm{df}=3 ; \mathrm{p}=0.138)$ and on "Moralistic/Ecologistic" attitudinal dimension (Kruskall-Wallis test: $\chi^{2}=3.606$; $\mathrm{df}=3 ; \mathrm{p}=0.307)$.

A total of $37 \%$ of all students reported direct experiences with toads. Statistically significant differences between student's ratings according to reported direct experience of toads were present for "Scientistic" attitudinal dimension (Mann-Whitney U test: $\mathrm{Z}=-3.87, \mathrm{p}<0.001)$ and "Negativistic" attitudinal dimension (Mann-Whitney $\mathrm{U}$ test: $\mathrm{Z}=-5.59, \mathrm{p}<$ 0.001). Students who reported direct experiences with toads rated statements of "Scientistic" and "Negativistic" attitudinal dimension higher (i.e., they were more interested to learn about toads and had less negative attitude) than students who reported no direct experiences with toads. On "Moralistic/Ecologistic" attitudinal dimension, students ratings didn't significantly differ according to reported direct experience with toads (Mann-Whitney $\mathrm{U}$ test: $\mathrm{Z}=-0.83$, $\mathrm{p}=0.409)$.

Girls showed more positive "Scientistic" and "Moralistic/Ecologistic" attitudes than boys (MannWhitney $U$ test: $Z=-2.65$ and 4.52 , both $\mathrm{p}<0.01$ ). While on "Negativistic" attitudinal dimension, ratings of girls didn't significantly differ from ratings of boys (Mann-Whitney U test: $\mathrm{Z}=-1.17, \mathrm{p}=0.241$ ). On more than $50 \%$ of statements girls ratings were significantly higher than ratings of boys (except for ratings of fear, where lower value means higher fear of toads) (Tab 2).

According to reported direct experiences with toads, sixth and seventh grade students rated "Scientistic" attitudinal dimension significantly different, while there were no statistically significant differences between ratings of students in eighth and ninth grade (Fig. 1). From Fig. 1 it can be seen that students with reported direct experiences with toads were more willing to learn about them than students without reported direct experiences. They contribute the most to the high overall average.

Table 2. Descriptive and inference statistics of individual item according to gender

\begin{tabular}{|c|c|c|c|c|c|c|}
\hline \multirow{2}{*}{ ITEMS } & \multicolumn{2}{|c|}{ BOYS } & \multicolumn{2}{|c|}{ GIRLS } & \multicolumn{2}{|c|}{ Mann-Whitney U } \\
\hline & Mean & SE & Mean & SE & Z & $p$ \\
\hline I am afraid of toads. (R) & 4.4 & 0.108 & 3.7 & 0.127 & -4.547 & $<0.001$ \\
\hline I would like to study toads in nature. & 2.8 & 0.134 & 3.0 & 0.125 & -0.882 & 0.378 \\
\hline I would like to hold a toad in my hands. & 2.7 & 0.135 & 2.6 & 0.149 & -0.933 & 0.351 \\
\hline I wouldn't like to hunt toads. & 3.3 & 0.153 & 3.9 & 0.139 & -2.647 & 0.008 \\
\hline Cars kill to many toads each year. & 3.6 & 0.140 & 4.2 & 0.096 & -3.068 & 0.002 \\
\hline Toads are disgusting animals. (R) & 3.4 & 0.136 & 3.2 & 0.129 & -1.403 & 0.161 \\
\hline Toads are very & 3.4 & 0.120 & 3.6 & 0.091 & -0.443 & 0.658 \\
\hline It would be for & 4.0 & 0.133 & 4.6 & 0.081 & -3.750 & $<0.001$ \\
\hline Hunting toads $\mathrm{fc}$ & 3.3 & 0.160 & 4.2 & 0.135 & -4.392 & $<0.001$ \\
\hline $\begin{array}{l}\text { When I am walking through the woods, I do not have a special wish to } \\
\text { meet a toad. }(\mathrm{R})\end{array}$ & 2.9 & 35 & 2.7 & 2 & -0.753 & 0.451 \\
\hline I would rather see a model of a toad than a live one. (R) & 3.2 & 0.145 & 3.1 & 0.149 & -0.256 & 0.798 \\
\hline I get bored when biologists are talking about toads. (R) & 2.8 & 0.135 & 3.5 & 0.107 & -3.269 & 0.001 \\
\hline I would rather see a movie about toads than watch them in nature. (R) & 3.2 & 0.144 & 3.5 & 0.130 & -1.725 & 0.085 \\
\hline Toads are of value as they eat mos & 4.2 & 0.110 & 4.2 & 0.085 & -0.603 & 0.546 \\
\hline I like to read about toads. & 2.3 & 0.123 & 2.5 & 0.099 & -1.167 & 0.243 \\
\hline I would like to learn about different species & 2.8 & 0.143 & 3.2 & 0.130 & -2.168 & 0.030 \\
\hline I would like to know how toads eat, smell and hear. & 3.1 & 0.136 & 3.6 & 0.116 & -2.756 & 0.006 \\
\hline Toads need to have rights too. & 3.4 & 0.139 & 4.2 & 0.090 & -4.459 & $<0.001$ \\
\hline Keeping toads in captivity is cruel. & 3.6 & 0.147 & 4.0 & 0.107 & -1.919 & 0.055 \\
\hline I could observe toads for a long time. & 3.0 & 0.145 & 2.9 & 0.103 & -0.809 & 0.418 \\
\hline I would like to have a toad at home. & 1.8 & 0.117 & 1.7 & 0.097 & -0.392 & 0.695 \\
\hline I would like to learn about environments where toads live. & 2.7 & 0.136 & 3.3 & 0.110 & -2.959 & 0.003 \\
\hline $\begin{array}{l}\text { We don't need to protect rain forests, because toads living there will } \\
\text { move elsewhere. (R) }\end{array}$ & 3.7 & 0.133 & 4.2 & 0.101 & -2.416 & 0.016 \\
\hline I would like to know how toads developed. & 3.1 & 0.136 & 3.5 & 0.111 & -1.943 & 0.052 \\
\hline Toads are ugly. (R) & 3.1 & 0.137 & 3.1 & 0.130 & -0.135 & 0.893 \\
\hline
\end{tabular}


Almost the same applies for "Negativistic" attitudinal dimension where students with reported direct experiences with toads had more positive attitude than students without reported direct experiences (Fig. 1). Ninth grade students were the only exception where no statistically significant differences in ratings between students with and students without reported direct experiences were found.

On "Moralistic/Ecologistic" attitudinal dimension, there were no differences found within each grade according to reported direct experiences with toads (Fig. 1).

According to reported direct experiences, there were statistically significant differences found within ratings of boys and within ratings of girls on two attitudinal dimensions, "Scientistic" and "Negativistic" (Fig. 2), while no differences were found on "Moralistic/Ecologistic" attitudinal dimension.

Multivariate analysis of independent variables effect on attitude and knowledge

Results of multivariate analysis show, that all three independent variables contributed significantly to this model (Tab. 3) with the strongest effect placed on reported experiences with toads. Even more, interaction reported direct experience $\times$ gender and reported direct experience $\times$ education level bordered statistical significance.

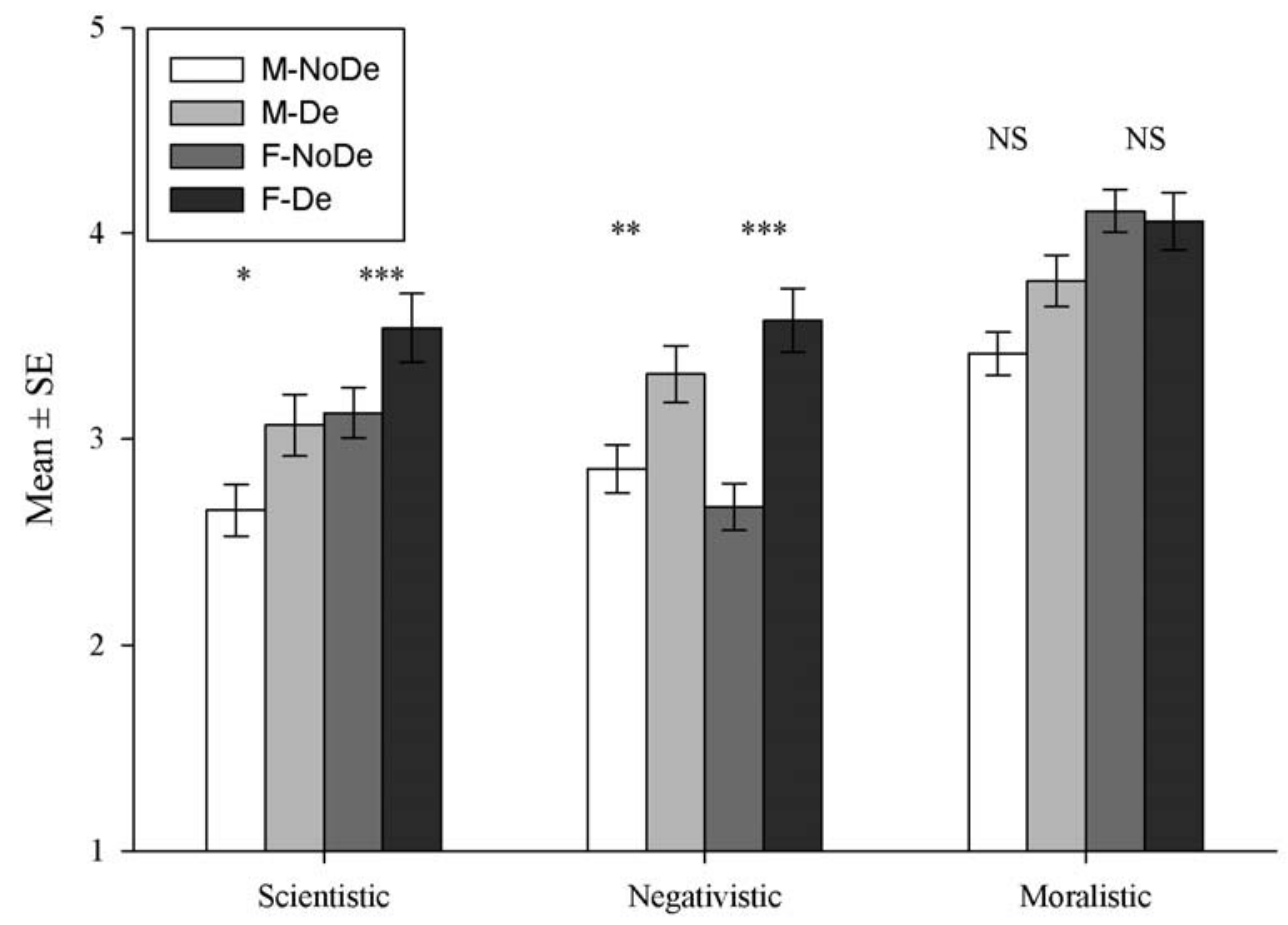

\section{The relationships between attitude dimensions}

When controlled for the effect of gender, education level-grade and reported direct experience with toads between attitude dimensions, partial correlations showed that "Scientistic" attitude score is most significantly correlated with the "Moralistic/Ecologistic" attitude dimension (Tab. 4). The "Scientistic" dimension also strongly correlated with the "Negativistic" attitude dimension. The lowest correlation was found between the "Moralistic/Ecologistic" and "Negativistic" attitude dimension.

\section{DISCUSSION}

In the past decade we witnessed growing interest in researching attitudes toward different animal species and animal groups. Beside researching attitude, there is also great emphasis placed on emotional factors that could influence attitude change. Direct experience with animals is supposed to have great influence on lowering negative feelings students have toward animals (Tomažič, 2008; Prokop et al., 2009b), therefore education should also include live animals in instruction (for a comment on issue of working with live animals please see Tomažič, 2011).

This study has shown that:

(1) the developed questionnaire is statistically appropriate for the use with at least primary school students.

Figure 2. Differences in attitudes toward toads according to gender and reported direct experiences. Lower score on negativistic scale means more negative attitude toward toads.

${ }^{* * *} p<0.001 ; * * p<0.01 ; * p<0.05$; NS = not significant. Legend: $\mathrm{M}=$ males, $\mathrm{F}=$ females, $\mathrm{NoDe}=$ no reported direct experience, $\mathrm{De}=$ reported direct experience. 
(2) all three independent variables, student grade, gender and reported direct experience have different influence on attitudes toward toads. Namely, students of higher grades are less interested to learn about toads than students of lower grades what is in line of several previous studies where interest in animals decreased as age of children increased (Prokop \& Tunnicliffe, 2008; Bjerke \& Østdahl, 2004). On the other hand, there was no difference on "Negativistic" and "Moralistic/Ecologistic" attitudinal dimension between students of different grades. It seems that direct experience lowers negative feelings toward animals and heightens interest in studying these animals. Males displayed less interest for animals and were not so opposed to inappropriate behaviour toward toads than females. On "Negativistic" attitudinal dimension, ratings of boys didn't differ significantly from ratings of girls.

(3) The strongest correlation was found between "Scientistic" and "Moralistic/Ecologistic" attitudinal dimensions, followed by correlation between "Scientistic" and "Negativistic" attitudinal dimension. Interestingly, ratings on "Moralistic/Ecologistic" attitudinal dimension showed the lowest correlation with ratings of "Negativistic" attitudinal dimension.

\section{"Scientistic" attitudinal dimension}

As in other studies (Yore \& Boyer, 1997; Prokop et al., 2009a,b), students in this study who reported direct experience with animals were more willing to learn about animals than students without direct experience. This could lead to greater acquisition of knowledge and more positive attitudes toward animals, consequently leading to more appropriate behaviour (Barney et al., 2005). Reported direct experience in this study had significant effect in students of lower grades, sixth and seventh grade but not in eighth and ninth grade. The results of this study are in line with Kellert's (1985) research and later research of Prokop and Tunnicliffe (2008). Students of lower grades were more prepared to learn about animal biology (structure and function) and ecology, than students in higher grades (Fig. 1). But what must be mentioned is that this interest was present mainly on account of students who reported having direct experiences with animals. This implies that students need to acquire direct experiences with animals in order to gain higher interest in studying them. It is known that an attitude based on a direct experience is more likely to affect an individual's behaviour (actual or intended) than an attitude formed on the basis of an indirect experience (Fazio \& Zanna, 1981). Furthermore, there was also a significant difference present in numbers of students with or without direct experience in different grades. Namely, proportionally higher number of sixth grade students reported having direct experiences with animals $(69 \%)$ than number of ninth grade students $(18 \%)$. A larger sample of students in the following study will hopefully allow for better conclusions about direct experience. As an argument, the results from one of the previous studies can be mentioned, where it was found that students with reported direct experiences before instruction and actual direct experiences in instruction benefited the most both in gaining knowledge and forming more positive attitude toward three amphibian species (Tomažič, 2008).

Girls expressed higher willingness to learn about toads than boys, what is contrary of what Prokop and Tunnicliffe (2008) found for students attitude toward bats and spiders. Here girls rated "Scientistic" dimension higher than boys (Fig. 2). That is probably because animal such as toad is not perceived as dangerous in a sense of physical harm but is more likely to cause infection or illness (Davey et al., 1998) and is for boys quite uninteresting. Bjerke and Østdahl (2004) for example reported that unpopular animals have higher

Table 3. GLM analysis of independent variables effect on attitude.

\begin{tabular}{lcccccc}
\hline Effect & Wilks' $\Lambda$ & $F$ & Hypothesis df & Error df & $p$ & Partial $\eta^{2}$ \\
\hline Gender & 0.890 & 7.148 & 3 & 174.0 & 0.000 & 0.110 \\
Education level & 0.874 & 2.673 & 9 & 423.6 & 0.005 & 0.044 \\
Direct experience & 0.865 & 9.018 & 3 & 174.0 & 0.000 & 0.135 \\
Gender $\times$ Education level & 0.961 & 0.772 & 9 & 423.6 & 0.643 & 0.013 \\
Gender $\times$ Direct experience & 0.957 & 2.626 & 3 & 174.0 & 0.052 & 0.043 \\
Education level $\times$ Direct experience & 0.911 & 1.847 & 9 & 423.6 & 0.058 & 0.031 \\
Gender $\times$ Education level $\times$ Direct experience & 0.968 & 0.625 & 9 & 423.6 & 0.776 & 0.011 \\
\hline
\end{tabular}

Table 4. Relationships between questionnaire dimensions (partial correlation coefficients

\begin{tabular}{lcc}
\hline & Negativistic & Moralistic/Ecologistic \\
\hline Scientistic & $0.444^{* * *}$ & $0.485^{* * *}$ \\
Negativistic & - & $0.243^{* *}$ \\
\hline${ }^{* * *} \mathrm{p}<0.001 ;{ }^{* *} \mathrm{p}<0.01$. &
\end{tabular}


ratings among boys. Prokop et al., (2009a,b) and Prokop and Tunnicliffe (2010) also found similar preferences for unpopular animals (predators, disease-relevant animals) in boys. This study didn't ask students about keeping pets what might additionally clarify the decrease of interest about toads. Namely, Prokop and Tunnicliffe (2010) reported decreasing number of pets at home as age of children increased what could be explained by their lower interest in animals.

\section{"Negativistic" attitudinal dimension}

Thompson and Mintzes (2002) study was looking into attitude dimensions about sharks and their "Naturalistic" attitude dimension was similar to "Negativistic" attitude dimension in this study. Overall average ratings in this study didn't differentiate boys and girls $(p>0.05)$. But in study of Thompson and Mintzes this difference occurred. Girls' attitude was more negative than the attitude of boys. Invertebrates also were rated as less popular by females than males (Prokop et al., 2010a).

The differences in ratings were found on individual items (Tab. 2). For example, boys reported less fear of toads than girls ("I am afraid of toads."). But still, averages of their ratings were on the level of disagreement with that statement (not afraid or undecided), both for boys and for girls.

Students reported level of fear ( $\mathrm{M}=3.7$ for girls) was not as strong as disgust and even average disgust ratings were not lower than 3.2, again for girls (lower values mean higher disgust and fear). Similar results about fear and disgust toward toads were found in a previous study (Tomažič, 2011). Some other studies also found that females generally report greater fear of different animals than males (Arrindell et al., 2003; Roskaft et al., 2003; Prokop et al., 2009a,b, Prokop et al., 2010a, Prokop \& Tunnicliffe 2010). The reason for less fear in boys can probably be contributed to the fact that lower fear of animals in males becomes expressed when males become sexually active. From evolutionary perspective, males have to risk more than females (Byrnes et al. 1999) and these risks in adult males would be interpreted as costly signals by which males advertise their physical abilities to females (see e.g. Hawkes, 1991 for discussion about costly signals in humans). Additional research involving males and females of various age groups is necessary to test this idea.

Disgust ratings toward toads were generally equal for boys and girls. Prokop et al. (2010a) faced similar problem where Turkish females showed the same fear/disgust of invertebrates than males, but in Slovakian sample the difference clearly favoured males (more positive ratings). They argued the lack of differences in ratings between Turkish males and females to the low average ratings (as in this study) and as consequence the lack of sufficient variation.

Items that were included in negativistic attitude dimension were beside negative emotions of fear and disgust also asking students about possibility of encountering or having direct contact with live toads. These values to some extent lowered average score on "Negativistic" dimension. Both "Negativistic and "Scientistic" dimension ratings were quite low compared to "Moralistic" attitude dimension (Fig. 2). As mentioned by Prokop and Tunnicliffe (2008) "Scientistic" and "Negativistic" attitude dimension can be misleading when interpreting potential behavioural intent. Students might report higher willingness to learn and at the same time report greater tendency to avoid situations that include meeting live animals. "Negativistic" attitude dimension in this study also included statements of possible avoidance from live animals and ratings on these statements to some extent lowered average score on this dimension. In Fig. 1 it can be seen that ratings of ninth grade students decreased overall average of that attitude dimension. This could probably be regarded as a result of students development, social preferences or lower reported experiences by ninth grade students. In other grades, students with or without reported direct experiences with toads were improving their negative attitude from sixth to eighth grade (Fig. 1). This could be due to our renewed science curricula that introduce some amphibian species first at the end of sixth grade, then in seventh and eighth grade. In contrast to the old curricula, it also proposes that students should meet live animals possibly in their natural settings. As they are learning about them from one school year to the other, they get to know them, so their interest in learning more about them diminishes. At the same time the students express less negative attitude through grades.

\section{"Moralistic" attitudinal dimension}

There were generally no differences on "Moralistic" dimension according to reported direct experiences with toads in each grade (Fig. 1). Also there were no differences in ratings within individual gender; between boys with and without direct experiences with toads, and between girls with and without direct experiences with toads (Fig. 2). From this it can be seen that direct experience might not influence how students perceive cruelty toward animals. But it must be noted that from this we cannot conclude that they both will react inappropriately if placed in situation where they will need to react to cruelty toward animals. As Barney et al. (2005) noted, that only higher moral sensitivity will not always produce environmentally friendly behaviours. People, who react mainly on a basis on that attitude dimension, can cause more harm than people with balanced attitude and appropriate knowledge. The same 
as in Thompson and Mintzes (2002) study about sharks, girls in this study expressed higher moral objections to the cruelty toward toads than boys.

\section{Limitation of the study}

In this study students were only asked (self-report) about their direct experiences with toads, therefore it cannot be treated as experimental. The possibility that some students who were more interested in toads (by unclear motivation) simply wanted to handle toads more than other children cannot be ruled out (for discussion see also Prokop, Prokop \& Tunnicliffe, 2008). Further experimental research in this field is needed to get more comparable results. The questionnaire in this study was constructed and tested for the purpose comparing different types of instruction on attitude change toward toads in primary and secondary school students.

Students were also not asked about their experiences with nature (i.e. "How many times do you go outside into the natural world?") or whether they lived on farms or not, what should be considered for future studies.

\section{ACKNOWLEDGEMENTS}

The paper is based on work supported by the Ministry of Education and Sport of the Republic of Slovenia and the European Social Fund in the framework of "Project: Development of Natural Science Competences" at the Faculty of Natural Sciences and Mathematics of the University of Maribor, Slovenia.

\section{REFERENCES}

Arrindell, W. A. (2000). Phobic dimensions: IV. The structure of animal fears. Behaviour Research and Therapy, 38 (5), 509-530.

Arrindell, W. A., Eisemann, M., Richter J., Tian, P. S., Oei, T. P. S, Caballo, V. E., et al. (2003). Phobic anxiety in 11 nations, Part I: Dimensional constancy of the five-factor model. Behaviour Research \& therapy, 41 (4), 461-479.

Association of Zoos and Aquariums. (n.d.). Retrieved June 20, 2011, from http://www.amphibianark.org/pdf /YOTF/WAZA \%20Global\%20InfoPack\%20English.p df.

Barney, E. C., Mintzes, J. J., \& Yen, C.-F. (2005). Assessing Knowledge, Attitudes, and Behavior toward Charismatic Megafauna: The Case of Dolphins. Journal of Environmental Education, 36 (2), 41-55.

Beebee, T. J. C., Griffiths, R. A. (2005). The amphibian decline crisis: A watershed for conservation biology? Biological Conservation, 125 (3), 271-285.

Bjerke, T., Østdahl, T. (2004). Animal-related attitudes and activities in an urban population. Anthrozöos, 17 (2), 109-129.
Blaustein, A. R., Kiesecker, J. M. (2002). Complexity in conservation: lessons from the global decline of amphibian populations. Ecology Letters, 5 (4), 597-608.

Byrnes, J., Miller, D., \& Schaffer, W. (1999). Gender differences in risk-taking: A meta-analysis. Psychological Bulletin, 125 (3), 367-383.

Curtis, V., Biran, A. (2001). Dirt, disgust, and disease: is hygiene in our genes? Perspectives in Biology and Medicine, 44 (1), 17-31.

Curtis, V., Aunger, R., Rabie, T. (2004). Evidence that disgust evolved to protect from risk of disease. Proceedings of the Royal Society B: Biological Sciences, 271(Suppl 4), S131S133.

Davey, G. C. L., McDonald, A. S., Hirisave, U., Prabhu, G. G., Iwawaki, S., Jim, C. I., et al. (1998). A cross-cultural study of animal fears. Behaviour Research and Therapy, 36 (7-8), 735-750.

Ekman P. (1999). Basic Emotions. Handbook of Cognition and Emotion. Dalgleish T. and Power M. J. (eds.). Sussex: UK, John Wiley \& Sons, 45-60.

European Parliament, Council, (2006). Recommendation of the European Parliament and of the Council of 18 December 2006 on key competences for lifelong learning. [Last access on: 5.5.2010; http://eurlex.europa.eu/LexUriServ/LexUriServ.do?uri=OJ:L:200 6:394:0010:0018:EN:PDF]

Fazio, R.H., Zanna, M.P. (1981). Direct experience and attitudebehavior consistency. Advances in experimental social psychology. Berkowitz L. (ur.). San Diego: CA, Academic Press, 161-202.

Gregori, J. (1996). Ogroženost in varstvo dvožive (Amphibia); The Amphibian Fauna (Amphibia) - Present State and Future Prospects. Narava Slovenije, stanje in perspektive: zbornik prispevkov o naravni dediščini Slovenije. Gregori, J., Martinčič A., Tarman K., Urbanc-Berčič O., Tome D. and Zupančič M. (eds.). Ljubljana, Društvo ekologov Slovenije, 362-367.

Hawkes, K. (1991). Showing off. Tests of an hypothesis about men's foraging goals. Ethology and Sociobiology, 12 (1), 29-54.

Hungerford, H. R., \& Volk, T. L. (1990). Changing learner behavior through environmental education. The Journal of Environmental Education, 21 (3), 8-21.

IUCN, Conservation International, and NatureServe. 2008. An Analysis of Amphibians on the 2008 IUCN Red List $<$ www.iucnredlist.org/amphibians $>$. Downloaded on 12 October 2010.

Kellert, S. R. (1985). Attitudes toward animals: age-related development among children. Journal of Environmental Education, 16 (3), 29-39.

Kellert, S. R. (1993). Values and perceptions of invertebrates. Conservation Biology, 7 (4), 845-855.

Kellert; S. R. (1996). The value of life: biological diversity and human society. Washington: DC, Island Press.

Kraus, S. J. (1995). Attitudes and the prediction of behavior a metaanalysis of the empirical literature. Personality and Social Psychology Bulletin, 21 (1), 58-75.

Lin, H., Cheng, L., Chen, P., \& Chang, M. (2008). Involving local communities in amphibian conservation: Taipei frog Rana taipehensis as an example. International Zoo Yearbook, 42 (1), 90-98. 
Lukas, K. E., \& Ross, S. R. (2005). Zoo Visitor Knowledge and Attitudes toward Gorillas and Chimpanzees. Journal of Environmental Education, 36 (4), 33-48.

Morgan, J. M. (1992). A theoretical basis for evaluating wildlife-related education-programs. American Biology Teacher, 54 (3), 153-157.

Morgan, J. M., \& Gramann, J. H. (1989). Predicting effectiveness of wildlife education programs: A study of students' attitudes and knowledge towards snakes. Wildlife Society Bulletin, 17 (4), 501-509.

Oaten, M., Stevenson, R., \& Case, T. (2009). Disgust as a Disease-Avoidance Mechanism. Psychological Bulletin, 135 (2), 303-321.

Prokop, P., Prokop, M., \& Tunnicliff e, S. D. (2008). Eff ects of keeping animals as pets on children's concepts of vertebrates and invertebrates. International Journal of Science Education, 30 (4), 431-449.

Prokop, P., Tunnicliffe, S. D. (2008): 'Disgusting animals': Primary school children's attitudes and myths of bats and spiders. Eurasia Journal of Mathematics, Science \& Technology Education, 4 (2), 87-97.

Prokop, P., Fančovičová, J., Kubiatko, M.(2009a). Vampires are still alive: Slovakian students' attitudes toward bats. Anthrozoös, 22 (1), 19 - 30.

Prokop, P., Özel, M., Uşak, M.(2009b). Cross-cultural comparison of student attitudes toward snakes. Society and Animals, 17 (3), $224-240$.

Prokop, P., Tunnicliffe, S.D. (2010). Effects of keeping pets on children's attitudes toward popular and unpopular animals. Anthrozoös, 23 (1), 21 - 35.

Prokop, P., Uşak, M., Fančovičová, J. (2010a). Health and the avoidance of macroparasites: A preliminary crosscultural study. Journal of Ethology, 28 (2), 345 - 351.

Prokop, P., Tolarovičová, A., Camerik, A., Peterková, V. (2010b). High school students' attitudes towards spiders: A cross-cultural comparison. International Journal of Science Education, 32 (12), 1665 - 1688.

Prokop, P., Fančovičová, J., Fedor, P. (2010c): Health is associated with anti-parasite behavior and fear of disease-relevant animals in humans. Ecological Psychology, 22 (3), $222-237$.

Randler, C., Ilg, A., \& Kern, J. (2005). Cognitive and emotional evaluation of an amphibian conservation program for elementary school students. Journal of Environmental Education. 37 (4), 43-52.

Røskaft, E., Bjerke, T., Kaltenborn, B. P., Linnell, J. D. C., \& Andersen, R. (2003). Patterns of self-reported fear towards large carnivores among the Norwegian public. Evolution \& Human Behavior, 24 (3), 184-198.

Thompson, T. L., \& Mintzes, J. J. (2002). Cognitive structure and the affective domain: on knowing and feeling in biology. International Journal of Science Education, 24 (6), 645-660.

Tomažič, I. (2008). The influence of direct experience on students' attitudes to, and knowledge about amphibians. Acta Biologica Slovenica, 51 (1), 39-49.

Tomažič, I. (2011). Seventh Graders’ Direct Experience with, and Feelings toward, Amphibians and Some Other Nonhuman Animals. Society and animals, 19 (3), 225-247.

Trombulak, S.C., Omland, K.S., Robinson, J.A., Lusk, J.J., Fleischner, T.L., Brown, G., and Domroese, M. (2004).
Principles of conservation biology: Recommended guidelines for conservation literacy from the Education Committee of the Society for Conservation Biology. Conservation biology, 18 (5), 1180-1190.

Tunnicliffe S. D., Reiss M. J. (1999). Building a model of the environment: how do children see animals? Journal of Biological Education, 33 (3), 142-148.

Uradni list RS, št. 82/2002. Pravilnik o uvrstitvi ogroženih rastlinskih in živalskih vrst $\mathrm{v}$ rdeči seznam. Available at: http://www.uradni-list.si/ (2.5.2010).

Yen, C.F., Yao, T.W., \& Chiu, Y.C. (2004). Alternative Conceptions in Animal Classification Focusing on Amphibians and Reptiles: A Cross-Age Study. International Journal of Science and Mathematics Education, 2 (2), 159-174.

Yore, L. B., \& Boyer, S. (1997). College students' attitudes towards living organisms: The influence of experience \& knowledge. American Biology Teacher, 59 (9), 558-563.

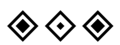

